\title{
Moving from building information models to digital twins for operation and maintenance
}

Qiuchen Lu PhD

Research Associate, Institute for Manufacturing, University of Cambridge, Cambridge, UK

Xiang Xie PhD

Research Associate, Institute for Manufacturing, University of Cambridge, Cambridge, UK (corresponding author: xx809@cam.ac.uk)

(Orcid:0000-0003-4601-9519)

\author{
Ajith Kumar Parlikad PhD \\ Reader, Institute for Manufacturing, University of Cambridge, Cambridge, \\ UK (Orcid:0000-0001-6214-1739) \\ Jennifer Mary Schooling PhD \\ Director, Centre for Smart Infrastructure and Construction, University of \\ Cambridge, Cambridge, UK \\ Eirini Konstantinou PhD \\ Research Associate, Institute for Manufacturing, University of Cambridge, \\ Cambridge, UK (Orcid:0000-0003-3652-5557)
}

With the rising adoption of building information modelling (BIM) for asset management within the architecture, engineering and construction sectors, BIM-enabled asset management during the operation and maintenance phase has been increasingly attracting more and more attention in both research and practice. This paper provides a comprehensive review and analysis of the development of state-of-the-art research and industry standards that impact on BIM and asset management within the operation and maintenance phase. However, in the aspects of both information richness and analytical capability, BIM is not always enough in delivering effective and efficient asset management, particularly in the operation and maintenance phase. Therefore, a framework for future development of smart asset management is proposed, integrating the concept of digital twins. Digital twins integrate artificial intelligence, machine learning and data analytics to create dynamic digital models that are able to learn and update the status of the physical counterpart from multiple information sources. The findings will contribute to inspiring novel research ideas and promote widespread adoption of digital-twin-enabled asset management within the operation and maintenance phase.

\section{Introduction}

Computerisation and digitisation are emerging to have a wide impact on the way that the life cycle of physical/engineering assets is managed (Parn et al., 2017). It is predicted that artificial intelligence (AI) could add $10 \%$ to the UK economy by 2030 (NIC, 2017). Additionally, improved data sharing and data utilisation could result in lower consumer bills, reduced impact on the natural environment and realise smart asset management. Particularly, advances in building information modelling (BIM) is likely to aid in reducing the time for updating databases in the operation and maintenance (O\&M) phase by 98\% (Ding and Drogemuller, 2009). The necessary technologies and approaches are more or less already available. However, data need to be stored, shared and analysed safely and securely, and therefore, technologies must be developed to ensure both security and efficiency.

Achieving a comfortable living environment and smart building management is a complex issue in the O\&M phase, which costs around $80 \%$ of whole life-cycle cost. Comprehensive information needs to be recorded and multiple stakeholders would be involved. The process of asset management in the O\&M phase is required to maintain integrity, validity and interoperability (Wetzel and Thabet, 2015). Consequently, an effective and intelligent asset management system is needed to maintain dynamic information, support various activities and contribute to a comfortable environment ( $\mathrm{Lu}$ et al., 2018). Various tools and systems have been implemented to enhance O\&M management, such as computerised maintenance management systems (CMMSs), computer-aided facility management (CAFM) systems, building automation systems (BASs) and integrated workplace management systems (Sapp, 2015). For instance, CMMS is a computerised system for O\&M management, which can record daily work orders, historical records, service requests and maintenance information. However, it still requires significant effort and time for facility management (FM) professionals to extract the diverse O\&M information that they need (Wetzel and Thabet, 2015). Thus, there is still a lack of an integrated platform that could manage information distributed in different databases and support various activities in the O\&M phase.

BIM, as a digital representation of a building or civil infrastructure asset, can be extended to form the basis for a database of all assets and facilitate the exchange of information in a unified and digital manner (Eastman et al., 2011). Moreover, in the O\&M phase, BIM can be used as an information source and a repository at the same time, supporting various activities in existing buildings and infrastructure (Volk et al., 2014). BIM has been successfully adopted in the design and construction phases. However, BIM still has limited adoption within asset management (Lu et al., 2018; Volk et al., 2014). The research related to BIM and asset management in O\&M is still at its infancy but is rapidly growing (Pishdad-Bozorgi et al., 2018).

BIM has proven to reduce information loss significantly during O\&M management ( $\mathrm{Lu}$ et al., 2018). In particular, BIM can integrate various digital products and asset data within a comprehensive digital platform - namely, a semantically rich integrated model, which manages different data resources 
Smart Infrastructure and Construction

Volume 174 Issue 2
Moving from building information

models to digital twins for operation and

maintenance

Lu, Xie, Parlikad, Schooling and Konstantinou effectively and efficiently (Succar, 2009). Thus, integration and interaction based on BIM can be achieved through model server technologies, single integrated/distributed federated databases, software-as-a-service solutions, Internet of things (IoT), sensor systems and so on (Bentley and Workman, 2003; Succar, 2009; Volk et al., 2014; Wilkinson, 2008). Hence, BIM and its integration properties become extremely invaluable to asset management in the O\&M phase that is aimed at obtaining longterm value and improving efficiency through implementing smart technologies and approaches. Indeed, the development of smart BIM-enabled asset management in the O\&M phase has an immense potential towards improved collaboration by way of an intelligent, efficient, interoperable and integrated platform.

Various integrated and comprehensive solutions for asset management in the O\&M phase have been proposed by adapting BIM and developing systems to improve interoperability and integration. For instance, Motawa and Almarshad (2013) proposed a case-based-reasoning (CBR)-integrated BIM system for building maintenance to improve the efficiency of decisionmaking and communication among different stakeholders. The restoration team of the Sydney Opera House also designed a unified central data repository integrating different resources to support effective O\&M management. However, it still lacks a detailed data capturing and maintenance approach (Ding and Drogemuller, 2009; Parsanezhad and Dimyadi, 2014). However, an integrated intelligent platform that can help monitor, update, communicate and integrate O\&M management issues in tandem is still waiting for continuous development and improvement.

Besides depicting the state-of-the-art implementation BIM in asset management, this paper discusses the benefits and limitations of current research and standards in asset management and potential developments towards digital twin (DT)-enabled asset management in the O\&M phase. DT refers to an integrated multifaceted and multiscale digital replica of physical assets, processes and systems (Kang and Hong, 2015). In the context of Digital Built Britain (DBB), a DT is 'a realistic digital representation of assets, processes or systems in the built or natural environment' (CDBB, 2018). From the perspective of information richness (as shown in Figure 1) and analytical capability, the concept of DT is broader than BIM. In this sense, DT not only is a model of the physical object or system, which connects between digital and physical assets, but also transmits data in at least one direction and monitors the physical system in real time. Moreover, DTs also support analytics, control and simulation functions (Peng et al., 2017).

Consequently, this study will focus on analysing the literature on asset management in the O\&M phase, including FM O\&M management, which commonly appear in publications and standards, at the building/infrastructure level (as shown in Figure 2). The hierarchical architecture of DT-enhanced asset management framework is proposed in this paper, which presents insight into the new field of DT-enabled asset management in the O\&M phase.

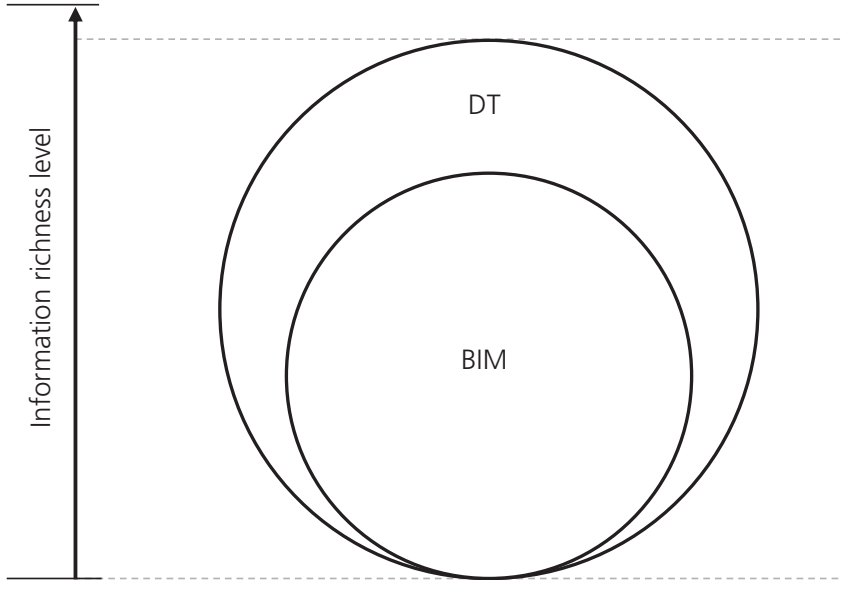

Figure 1. Classifications of BIM and DT

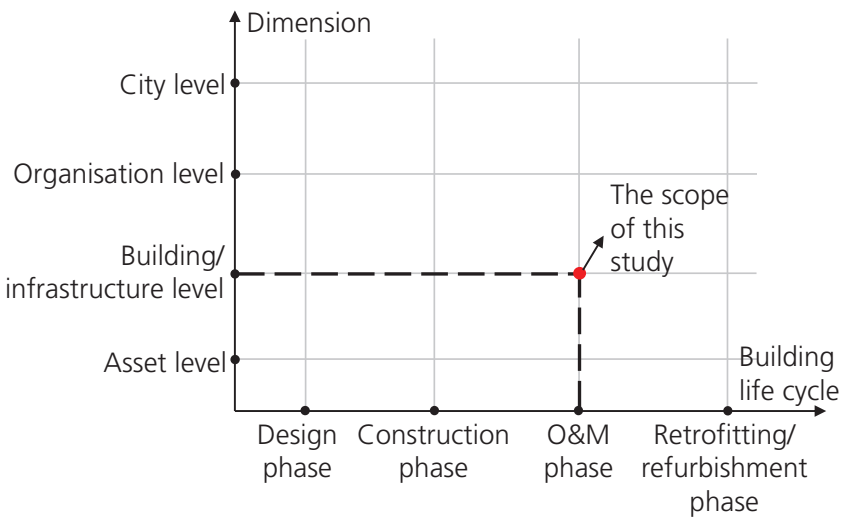

Figure 2. Research scope of this study

\section{Current research of BIM-enabled asset management}

Considering BIM for asset management, a bunch of academic publications were reviewed. The literature search was conducted on three academic databases (Scopus, ScienceDirect and Web of Science) that had been chosen for their comprehensive coverage on engineering and computation in construction and which cover a large number of journal and conference publications. The search was restricted to the application of BIM for asset management in O\&M/FM. Numerous recent developments not only focus on implementation and research in BIM-enabled asset management areas from technical aspects (Aziz et al., 2016; Gray et al., 2013) but also put great efforts in improving the performance of asset management in the O\&M phase from the perspective of management and organisation (Akbarnezhad et al., 2014; Chotipanich, 2004). These improvements can be classified as technology-related issues, information-related issues and organisation-related issues (Alvarez-Romero, 2014; Volk et al., 2014). 
The effectiveness of asset management in the O\&M phase will heavily rely on continuous information on asset conditions and performances, reliable communication channels and properly documented professional knowledge from previous experience (Alvarez-Romero, 2014; Lu et al., 2018; Parn et al., 2017). Obviously, BIM would aid in overcoming some of the complex problems in the O\&M phase (Love et al., 2015; Sabol, 2008). Building/infrastructure-related information can be directly or indirectly integrated within available digital technologies in a BIM-enabled environment. As shown in Table 1, many researchers have focused on developing BIM-enabled asset management systems facilitating high-performance O\&M. Targets and benefits of current BIM-enabled asset management during O\&M can be summarised as follows

- accurate and efficient support for decision-making, monitoring and communication
- easy retrieval and storage of maintenance, inventory, warranty, installation and operation data

- enhanced collaboration and increased visualisation for stakeholders

- effective management and planning of orders, activities, schedules, labour and space

- convenient maintenance and tracking of assets

- optimised use of fuel, utilities and materials

- facilitation of emergency evacuation planning.

The existing asset management approaches to integrating new technologies, information and further embracing organisational issues is a major challenge (Wong et al., 2018). Although a large amount of effort has been made in BIM-enabled asset management, the key problems to its current implementation and research are still unsolved. The reasons can be the lack of awareness of the potential benefits of smart assets (e.g. BIM) to

Table 1. Brief summary of BIM-enabled asset management development

\begin{tabular}{|c|c|c|c|}
\hline Author (year) & Data sources & Algorithms & Key contribution \\
\hline Shen et al. (2012) & $\begin{array}{l}\text { Wireless sensor/RFID- } \\
\text { based real-time asset } \\
\text { tracking, BIM }\end{array}$ & Agent-based web services & $\begin{array}{l}\text { Presenting a conceptual framework of the agent- } \\
\text { based service-oriented integration approach for } \\
\text { facility life-cycle information integration }\end{array}$ \\
\hline $\begin{array}{l}\text { Dibley et al. } \\
\text { (2012) }\end{array}$ & Sensor, IFC & $\begin{array}{l}\text { Ontology development including sensor and } \\
\text { building ontology }\end{array}$ & $\begin{array}{l}\text { Presenting an intelligent multi-agent software } \\
\text { framework (OntoFM) supporting real-time } \\
\text { building monitoring }\end{array}$ \\
\hline Lee et al. (2013) & $\begin{array}{l}\text { Sensor, BIM, GIS, } \\
\text { ubiquitous sensor } \\
\text { network, urban object } \\
\text { identification }\end{array}$ & $\begin{array}{l}\text { Integration of facility-related information and } \\
\text { integration of management functions }\end{array}$ & $\begin{array}{l}\text { Presenting intelligent urban FM for real-time } \\
\text { emergency response }\end{array}$ \\
\hline Ko et al. (2013) & $\begin{array}{l}\text { RFID, web-based } \\
\text { system, database }\end{array}$ & $\begin{array}{l}\text { Four-layer fuzzy neural network model, } \\
\text { scheduling theory }\end{array}$ & $\begin{array}{l}\text { Developing a web-based RFID FM system for } \\
\text { enhancing FM efficiency }\end{array}$ \\
\hline $\begin{array}{l}\text { Lin and Su (2013), } \\
\text { Lin et al. (2014) }\end{array}$ & $\begin{array}{l}\text { Mobile, barcode, } \\
\text { database, BIM }\end{array}$ & An information centre for data querying & $\begin{array}{l}\text { Proposing a mobile automated BIM-based FM } \\
\text { system for FM staff in the O\&M phase }\end{array}$ \\
\hline $\begin{array}{l}\text { Motamedi et al. } \\
\text { (2014) }\end{array}$ & CMMS, Cobie, IFC, BIM & $\begin{array}{l}\text { Data integration by way of connecting } \\
\text { unique IDs; knowledge capture using fault } \\
\text { trees }\end{array}$ & $\begin{array}{l}\text { Providing a knowledge-assisted BIM-based visual } \\
\text { analytics approach for failure root-cause } \\
\text { detection in FM }\end{array}$ \\
\hline $\begin{array}{l}\text { Kang and Hong } \\
\text { (2015) }\end{array}$ & GIS, BIM, IFC, CityGML & $\begin{array}{l}\text { BIM/GIS-based information extract, } \\
\text { transform and load architecture }\end{array}$ & $\begin{array}{l}\text { Proposing a software architecture for the effective } \\
\text { integration of BIM into a GIS-based FM system }\end{array}$ \\
\hline $\begin{array}{l}\text { Róka-Madarász } \\
\text { et al. (2016) }\end{array}$ & CAFM, CAD, database & $\begin{array}{l}\text { Top-down object hierarchy; geometric } \\
\text { description language }\end{array}$ & $\begin{array}{l}\text { Elaborating a methodology for gathering building } \\
\text { O\&M cost data }\end{array}$ \\
\hline $\begin{array}{l}\text { Shalabi and } \\
\text { Turkan (2016) }\end{array}$ & BIM, IFC, BEMS, BAS & $\begin{array}{l}\text { A schema that enables the integration of } \\
\text { data; a process linking alarm reports of } \\
\text { equipment failures with IFC BIM }\end{array}$ & $\begin{array}{l}\text { Proposing an automated process that responds to } \\
\text { alarms by retrieving alarms reported by FM } \\
\text { systems for corrective maintenance }\end{array}$ \\
\hline Peng et al. (2017) & Data warehouse, BIM & $\begin{array}{l}\text { Clustering algorithm; cluster-based frequent } \\
\text { pattern mining algorithm }\end{array}$ & $\begin{array}{l}\text { Proposing a BIM-based data mining approach for } \\
\text { extracting meaningful patterns and detecting } \\
\text { improper records }\end{array}$ \\
\hline $\begin{array}{l}\text { Arslan et al. } \\
(2017)\end{array}$ & BIM, sensor & Hadoop; distributed storage & Developing a proactive safety FM system \\
\hline $\begin{array}{l}\text { Suprabhas and } \\
\text { Dib (2017) }\end{array}$ & BIM, sensor, Cobie & Data integration and visualisation & $\begin{array}{l}\text { Developing an application that integrates sensor } \\
\text { data and reports the data by way of the virtual } \\
\text { model of the building }\end{array}$ \\
\hline Hu et al. (2018) & $\begin{array}{l}\text { BIM, GIS, BAS, web } \\
\text { service, QR code/RFID }\end{array}$ & $\begin{array}{l}\text { Logic chain generation algorithm; equipment } \\
\text { identification and grouping algorithm }\end{array}$ & $\begin{array}{l}\text { Developing a cross-platform mechanical, electrical } \\
\text { and plumbing management system }\end{array}$ \\
\hline Chen et al. (2018) & BIM, IFC, FM systems & $\begin{array}{l}\text { An algorithm used for optimal maintenance } \\
\text { path planning; Dijkstra algorithm used for } \\
\text { maintenance scheduling }\end{array}$ & $\begin{array}{l}\text { Proposing a BIM-based framework for automatic } \\
\text { scheduling of facility maintenance work orders }\end{array}$ \\
\hline
\end{tabular}

BEMS, building energy management systems; CAD, computer-aided design; Cobie, Construction Operations Building Information Exchange; GIS, geographic information system; Hadoop, highly archived distributed object-oriented programming; IFC, Industry Foundation Classes; RFID, radio-frequency identification devices 
Smart Infrastructure and Construction

Volume 174 Issue 2
Moving from building information

models to digital twins for operation and

maintenance

Lu, Xie, Parlikad, Schooling and Konstantinou the O\&M phase (Codinhoto and Kiviniemi, 2014; Lu et al., 2018), the lack of demonstrators in the real world of BIM-enabled asset management implementations (Becerik-Gerber et al., 2011) and the lack of a well-organised framework to design customised asset management in the O\&M phase.

Integration of different technologies and enlarging their intellectual capabilities are suggested to develop benchmarks corresponding to different use case scenarios. How to collect, store, manage and maintain various data resources (including FM systems), and to process the collected huge volume of data for making decisions effectively and intelligently, is all needed to be studied systematically in future research. There is still a lack of practical decision-making algorithms applied to predict and locate failure issues in daily asset management. According to Matarneh et al. (2019), a high growth rate of publications is shown in optimising O\&M management. However, the realisation of CBR modules is applicable only to certain scenarios, due to the oversimplification of mechanisms. Thus, improvement in the reliability and generalisation of technology and integration of information is an indispensable step towards smart BIM-enabled asset management for O\&M. Moreover, enhancing collaboration and interoperability from organisational views is also crucial in order to eliminate time-consuming manual processes and to facilitate maintenance activities for FM professionals.

\section{Industry standards and their scopes}

\subsection{Overall introduction of industry standards}

This section aims to review the current industry standards, specification and guidance as produced by standardisation organisations and regulatory bodies, in the domains of BIM and asset management. As seen from the last section, the challenge to implementing BIM within asset management is multifaceted, with one of the key challenges being the information capture, exchange, use and management throughout an asset whole life (design, construction, O\&M and disposal/renew). As such, it is also a requirement to review data-interoperability-related standards within the scope of BIM and asset management, most notability the exchange of information from the design and construction phase into the O\&M phase.

There is an array of standards that focus on BIM and information management processes within an asset's life cycle; the most comprehensive standards have been developed by BSI and ISO. Figure 3 highlights the key standards and specifications as per the associated life cycle. The bulk of the standards focus on the design and construction phase. A few standards that are associated with the O\&M phase focus on the exchange of information and geometry from design and construction into the O\&M phase and are not specifically focused on using BIM for asset management. Furthermore, there is a strong focus to support the end-user, operator and maintainer engagement at the easy stages within the design phase to capture their requirements.

\subsection{Asset management standards}

Asset management is a set of management processes and systems that encompass the management of an asset throughout its whole life cycle. This includes management of the physical asset and the related digital information within the context of the organisation. One of the key objectives on implementing an asset management

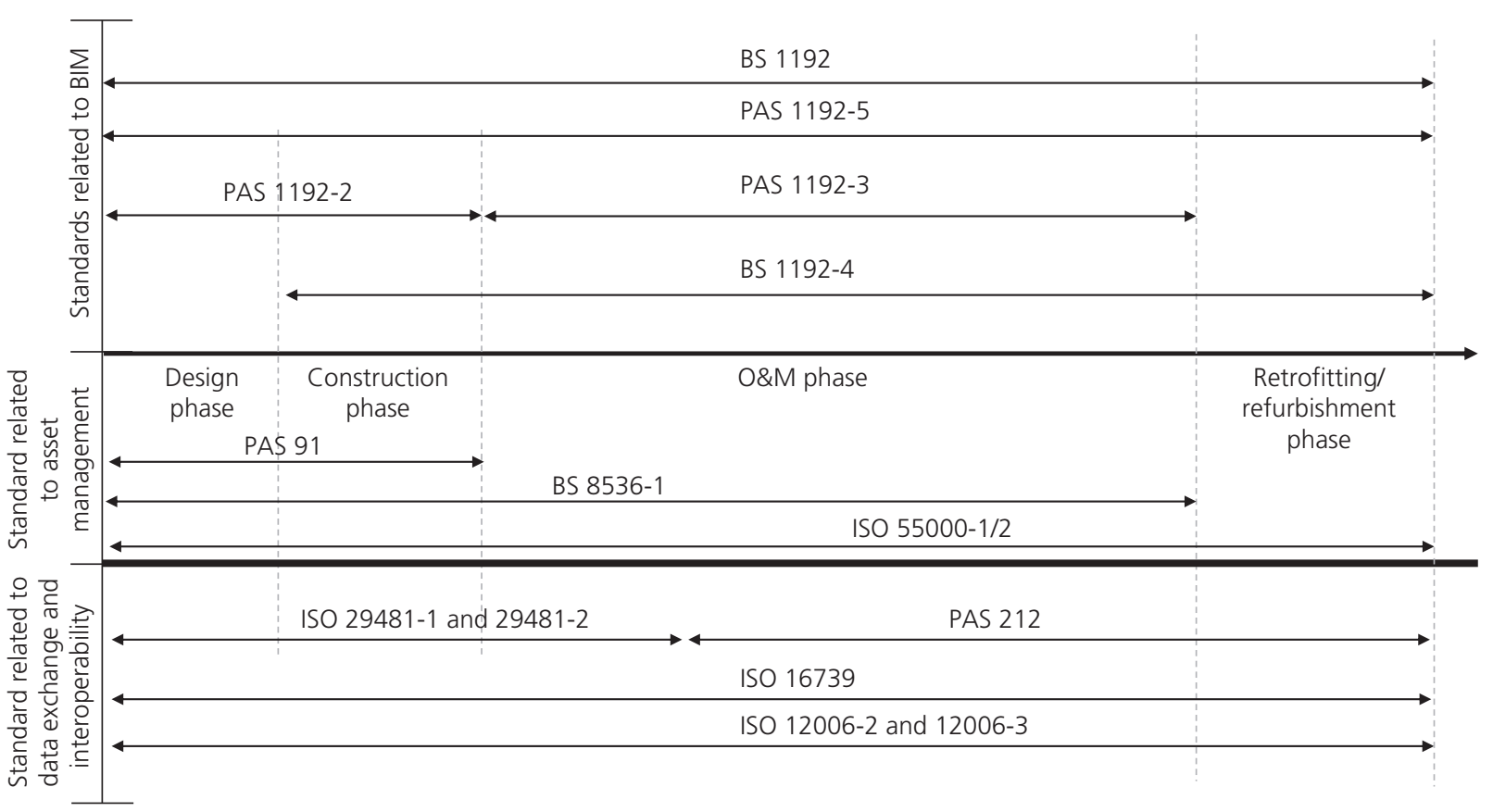

Figure 3. Summary of standards throughout an asset's whole life 
Smart Infrastructure and Construction

Volume 174 Issue 2
Moving from building information

models to digital twins for operation and

maintenance

Lu, Xie, Parlikad, Schooling and Konstantinou system is the ability to diffuse the traditional organisational siloed effect - for example, the capital works department not consulting the maintenance department for their requirements within new construction work.

ISO 55000:2014 (formally PAS 55/1/2) is a series of standards (three in total) that focus on the development of an asset management system for an asset-centric organisation. The standards are strategic in nature and support the management processes. This includes overview, principles, terminology, requirements and guidance for the application of the asset management requirements. A fundamental goal of asset management involves the balancing of cost, opportunities and risk against the desired performance of assets, to achieve the organisation's objectives. The performance of the assets can be measured in different value requirements, including not just the traditional measurement of financial value but also environmental and social value.

Furthermore, an industry representative body for asset managers in the UK, the Institute of Asset Management (IAM), has developed a collection of guidance documentation in collaboration with the industry to support the development of an asset management system. This guidance includes the development of asset-management-related documentation, developing performance measures, how to make improvements of the concepts and philosophy of asset management.

Table 2 summarises the key documentation related to asset management. The scope of asset management is broad, as it encompasses an asset's whole life and its value within an organisation's context. The standards are strategic in nature and provide a framework with associated processes for the development of an asset management system. While the standards provide the foundation for the development of an asset management system, they are limited in providing technical guidance. First, they fail to incorporate the emerging BIM processes, limiting the use of BIM within the O\&M phase of an asset. Second, not an efficient amount of focus is given to the information management process requirements within asset management. Finally, no framework is given that aids in aligning the organisational requirements with the asset information requirements and limiting the value of information that is collected from the organisation's assets.

\subsection{BIM standards}

BIM is an emerging process of designing, constructing or operating a building or infrastructure asset using digital objectoriented information. The development and implementation throughout the different life cycles of an asset are supported by an array of standards that have been developed by multiple country standard and regulation organisations. Most notably, the BSI has developed a comprehensive array of BIM-related standards focusing on individual life-cycle phases, including design, construction and operation. The BSI BIM-related standards lay down the foundation for how information should be defined, collected, exchanged, stored, used and disposed within the context of BIM information management processes. While BIM has been widely adopted within the design and construction phase, its adoption within the O\&M phase is limited. This is partly due to the multifaceted complex challenges of asset management and the alignment of the asset management frame to the BIM information management processes.

Table 2 summarises the key specifications and standards for BIM and their associated life-cycle phase. As can be seen, the scope of BIM is broad and encompasses the information management processes of an asset's whole life with many stakeholders. While the standards provide the theory and concept of BIM, several limitations are summarised in this paper. First, the concept is well described, but there is no methodology provided for implementation. Second, due to the broadness of BIM, the standards and specifications often lack technical details. Finally, PAS 1192-3 BIM for the O\&M phase fails to address the multifaceted challenges within adopting BIM for the O\&M phase. The summarised BIM standards have been created in isolation of any organisational management processes and as such fail to address the core processes of asset management (BSI, 2013b, 2014a). Furthermore, they lack support to allow a holistic organisational adoption of BIM, particularly in the O\&M phase. This is partly due to the standard's failure of clearly addressing stakeholder requirements within the BIM domain and simplifying the exchange from design/construction into the O\&M phase and lack of understanding of how information is used within the O\&M phase.

\subsection{Data exchange and interoperability standards}

To support the implementation of BIM and asset management, there is a fundamental need to standardise the exchange of geometric and non-geometric information among different stakeholders in the O\&M phase, and this requirement has resulted in a concept called OpenBIM. OpenBIM is a set of open-source data standards for the exchange of information between BIM authoring and validation tools. Most notably, buildingSmart has aided in developing the open-source data format Industry Foundation Classes (IFC) that supports the exchange of BIMrelated information and has been widely adopted by software developers. One of the key advantages of IFC is the interoperability that it enables, supporting the exchange of BIM models between different enterprise software providers. For example, a designer can exchange the IFC model with the quantity surveyor about cost estimation issues without using incompatible native formats. The overall goal of IFC is to support the exchange of information within an open-source standard throughout an asset's whole life, and this broad goal makes it an extensible information model (Shalabi and Turkan, 2016).

Furthermore, Construction Operations Building Information Exchange (Cobie) is the UK government's chosen information exchange schema for BIM-related information, alongside the BIM 
Table 2. Brief summary of standards related to asset management, BIM and data exchange and interoperability

\begin{tabular}{|c|c|c|c|c|}
\hline Standard type & Standard title & Key focus area & $\begin{array}{l}\text { Alignment to } \\
\text { other } \\
\text { standards }\end{array}$ & Reference \\
\hline \multirow{7}{*}{$\begin{array}{l}\text { Asset- } \\
\text { management- } \\
\text { related standards }\end{array}$} & \multirow{2}{*}{$\begin{array}{l}\text { ISO 55000: Asset management - overview, } \\
\text { principles and terminology } \\
\text { ISO 55001: Asset management - } \\
\text { management systems - requirements }\end{array}$} & \multirow{2}{*}{$\begin{array}{l}\text { An overview of an asset management } \\
\text { system with key principles and terminology } \\
\text { Defines the requirements for the } \\
\text { development of an asset management } \\
\text { system }\end{array}$} & $\begin{array}{l}\text { ISO } 55001 \\
\text { ISO } 55002\end{array}$ & ISO (2014a) \\
\hline & & & $\begin{array}{l}\text { ISO } 55000 \\
\text { ISO } 55002\end{array}$ & ISO (2014b) \\
\hline & $\begin{array}{l}\text { ISO 55002: Asset management - } \\
\text { management systems. Guidelines for the } \\
\text { application of ISO } 55001\end{array}$ & $\begin{array}{l}\text { Provides guidance on management } \\
\text { processes for meeting the requirements } \\
\text { outlined in ISO } 55001\end{array}$ & $\begin{array}{l}\text { ISO } 55000 \\
\text { ISO } 55001\end{array}$ & ISO (2018) \\
\hline & Asset Management - an Anatomy (IAM) & $\begin{array}{l}\text { A coherence industry guidance to asset } \\
\text { management within } 39 \text { subject areas } \\
\text { within six categories }\end{array}$ & - & IAM (2015) \\
\hline & The Asset Management Landscape & $\begin{array}{l}\text { A framework for enabling knowledge and } \\
\text { information compared, analysed and } \\
\text { aligned around a common understanding } \\
\text { of the discipline of asset management }\end{array}$ & ISO 5500-1/2 & IAM (2014) \\
\hline & $\begin{array}{l}\text { BS 8536: Briefing for design and } \\
\text { construction (parts } 1 \text { and 2) }\end{array}$ & $\begin{array}{l}\text { Provides recommendation for briefing on } \\
\text { the operational requirements during the } \\
\text { design and construction phase }\end{array}$ & $\begin{array}{l}\text { ISO } 55000-1 / 2 \\
\text { PAS } 1192-2 / 3\end{array}$ & $\begin{array}{l}\text { BSI (2015a, } \\
\text { 2016a) }\end{array}$ \\
\hline & $\begin{array}{l}\text { PAS 91:2013: Construction prequalification } \\
\text { questionnaires }\end{array}$ & $\begin{array}{l}\text { Provides a common set of questions to be } \\
\text { asked of the supply chain to validate } \\
\text { whether they can meet the operational } \\
\text { requirements }\end{array}$ & $\begin{array}{l}\text { ISO } 55000-1 / 2 \\
\text { PAS } 1192-3\end{array}$ & BSI (2013a) \\
\hline \multirow[t]{5}{*}{$\begin{array}{l}\text { BIM-related } \\
\text { standards }\end{array}$} & $\begin{array}{l}\text { BS 1192-2007 + A22016: Collaborative } \\
\text { production of architectural, engineering and } \\
\text { construction information. Code of practice }\end{array}$ & $\begin{array}{l}\text { Development of a design collaboration data } \\
\text { environment for the sharing of design- } \\
\text { related information }\end{array}$ & PAS $1192-2 / 3 / 5$ & BSI (2007) \\
\hline & $\begin{array}{l}\text { PAS 1192-2: Specification for information } \\
\text { management for the capital/delivery } \\
\text { phase of construction projects using BIM }\end{array}$ & $\begin{array}{l}\text { Defines a framework for the development } \\
\text { of BIM processes within the construction } \\
\text { phase }\end{array}$ & $\begin{array}{l}\text { BS } 1192 \\
\text { PAS-1192-5 }\end{array}$ & BSI (2013b) \\
\hline & $\begin{array}{l}\text { PAS 1192-3: Specification for information } \\
\text { management for the operational phase of } \\
\text { assets using building information modelling }\end{array}$ & $\begin{array}{l}\text { Focuses on the O\&M phase of an asset, } \\
\text { introducing the concept of an asset } \\
\text { information model }\end{array}$ & $\begin{array}{l}\text { ISO } 55000-1 / 2 / \\
\text { BS } 1192-4\end{array}$ & BSI (2014a) \\
\hline & $\begin{array}{l}\text { PAS 1192-5: Specification for security- } \\
\text { minded building information modelling, } \\
\text { digital built environments and smart asset } \\
\text { management }\end{array}$ & $\begin{array}{l}\text { Framework for a security-minded approach } \\
\text { to BIM information management } \\
\text { processes as defined within PAS 1192-2 }\end{array}$ & $\begin{array}{l}\text { ISO } 55000-1 / 2 \\
\text { PAS } 1192-2 / 3\end{array}$ & BSI (2015b) \\
\hline & Government Soft Landing & $\begin{array}{l}\text { Defines a framework for the delivery of } \\
\text { information thought the life cycle of an } \\
\text { asset }\end{array}$ & $\begin{array}{l}\text { PAS } 1192-3 \\
\text { BS } 1192-4 \\
\text { ISO } 55000-1 / 2\end{array}$ & $\begin{array}{l}\text { Cabinet } \\
\text { Office } \\
\text { (2013) }\end{array}$ \\
\hline \multirow{6}{*}{$\begin{array}{l}\text { Data-exchange- } \\
\text { and } \\
\text { interoperability- } \\
\text { related standards } \\
\text { within asset } \\
\text { management and } \\
\text { BIM aspects }\end{array}$} & $\begin{array}{l}\text { BS 1192-4: Collaborative production of } \\
\text { information. Fulfilling employer's } \\
\text { information exchange requirements using } \\
\text { COBie. Code of practice }\end{array}$ & $\begin{array}{l}\text { Defines an information data schema for the } \\
\text { exchange of operation-related information } \\
\text { throughout an asset's whole life }\end{array}$ & $\begin{array}{l}\text { PAS } 1192-3 \\
\text { ISO } 16739 \\
\text { (ISO, 2013) }\end{array}$ & BSI (2014b) \\
\hline & $\begin{array}{l}\text { ISO 16739: Industry Foundation Classes } \\
\text { (IFC) for data sharing in the construction } \\
\text { and facility management industries }\end{array}$ & $\begin{array}{l}\text { Open-source and vendor-neutral exchange } \\
\text { format for the example of BIM-related } \\
\text { geometry and information }\end{array}$ & $\begin{array}{l}\text { ISO } 29481 \\
\text { ISO } 12006-3 \\
\text { (ISO, 2007) }\end{array}$ & ISO (2013) \\
\hline & $\begin{array}{l}\text { ISO 29481-1: Building information } \\
\text { models - information delivery manual }\end{array}$ & $\begin{array}{l}\text { A methodology that links business processes } \\
\text { undertaken with the construction of an } \\
\text { asset with the specific information } \\
\text { required by these processes }\end{array}$ & $\begin{array}{l}\text { ISO } 16739 \\
\text { PAS } 1192-3\end{array}$ & ISO (2016) \\
\hline & $\begin{array}{l}\text { ISO 29481-2: Building construction - } \\
\text { organization of information about } \\
\text { construction works - framework for } \\
\text { classification }\end{array}$ & $\begin{array}{l}\text { Defines a framework for the development } \\
\text { of a classification system within the built } \\
\text { environment }\end{array}$ & $\begin{array}{l}\text { ISO } 12006-3 \\
\text { BS } 1192 \\
\text { PAS } 1192-2 / 3\end{array}$ & ISO (2012) \\
\hline & $\begin{array}{l}\text { ISO 12006-2: Building construction - } \\
\text { organization of information about } \\
\text { construction works - framework for } \\
\text { object-oriented information }\end{array}$ & $\begin{array}{l}\text { Defines a framework for the development } \\
\text { of an ontology to use within object- } \\
\text { orientated design }\end{array}$ & ISO 12006-2 & ISO (2015) \\
\hline & $\begin{array}{l}\text { PAS 212: Automatic resource discovery for } \\
\text { the Internet of Things - specification }\end{array}$ & $\begin{array}{l}\text { Design of a service for loT, widely adopted } \\
\text { in practical applications such as smart } \\
\text { cities }\end{array}$ & $\begin{array}{l}\text { BS } 1192-4 \\
\text { ISO } 16739\end{array}$ & BSI (2016b) \\
\hline
\end{tabular}


model and PDF documentation. The purpose is to create a structured approach for the exchange of information throughout an asset's whole life cycle. Cobie is a structured spreadsheet that can be populated by multiple stakeholders (facility manager, supplier etc.) and exchanged with the asset owner at predefined time or event milestones. The O\&M information captured within Cobie is a subset of the IFC data model, called a Model View Definition. While Cobie provides a simple and user-friendly approach (through spreadsheets) to the exchange of information throughout many stakeholders within an asset's life cycle, it is limited as a central validation process and risks information being lost within multiple spreadsheets, in comparison with a centrally controlled database/platform. Furthermore, the data entities, types and parameters required for FM using IFC and Cobie are still limited. More complicated data types in the O\&M phase are needed (Hamledari et al., 2017; Motamedi et al., 2014).

\subsection{Findings}

While, there is a growing set of standards that aim to enable the development of BIM within O\&M and asset management, there is a fundamental lack of a framework to support this development. Most notably, there are no holistic overarching frameworks that support the alignment of strategic, process and technical standards. This is witnessed within the standard for classification of built environment assets (ISO 12006-2), as this standard does not align to the information management processes for the built environment assets (BSI, 2014a; ISO, 2014a).
Furthermore, the standards have often been developed for individual life cycles and disciplines, resulting in limited usage throughout the whole-life cycles, as can be witnessed within the limited IFC classes and property sets that have limited support for infrastructure projects and O\&M requirements. Finally, there is a lack of the understanding of the organisational context of asset owners. While ISO 55000 supports the development of management processes within asset management, it does not align to information management processes such as PAS 1192-3 or ISO 12006-2, therefore creating a disconnection from the organisational context and information management processes for their built environment assets.

\section{Limitations of BIM-enabled asset management in O\&M}

Many organisations and researchers have made significant efforts to accelerate the development of BIM-enabled asset management in the O\&M phase from technology, information, organisation and standard perspectives. There are still many issues that need to be addressed to meet the anticipation of effective and efficient O\&M (Ding et al., 2009; Lu et al., 2018; Motamedi et al., 2014; Volk et al., 2014). Based on the preceding analysis, corresponding limitations and gaps are still needed to put forward from these four perspectives. Table 3 provides a comprehensive summary of limitations and gaps in current research and standards for achieving smart asset management in the O\&M phase.

Table 3. Limitations and gaps of current research and standards for developing smart asset management in O\&M phases

\begin{tabular}{|c|c|c|}
\hline \multirow[t]{4}{*}{$\begin{array}{l}\text { Technology-related } \\
\text { issues }\end{array}$} & a & $\begin{array}{l}\text { Lacking a well-organised demonstrator and guideline for technology selection, design and integration } \\
\text { Lacking integration of BIM with various CAFM systems }\end{array}$ \\
\hline & - & $\begin{array}{l}\text { Lacking integration of BIM with other systems - for example, locating and navigating in a complex BIM } \\
\text { environment is difficult when barcoding/tags are not properly linked with BIM }\end{array}$ \\
\hline & a & Lacking integration among various applied systems \\
\hline & a & Lacking clear and logical plans for updating as-is BIM \\
\hline \multirow[t]{7}{*}{$\begin{array}{l}\text { Information-related } \\
\text { issues }\end{array}$} & ! & $\begin{array}{l}\text { Lacking a predefined strategy of transforming different information - for example, natural languages, expert } \\
\text { experience and digital data }\end{array}$ \\
\hline & ! & Lacking a customised and extensible database for different types of information \\
\hline & घ & Information aspects in the CAFM systems not matching those in the BIM-authoring tools \\
\hline & - & Lacking clear defined strategies for information saving, exchanging and sharing \\
\hline & घ & Lacking specifying LOD requirements for BIM in the O\&M phase \\
\hline & - & Lacking specific information requirements according to the organisational roles \\
\hline & - & Lacking knowledge of specifying requirements of asset management early in the design phases \\
\hline \multirow[t]{4}{*}{$\begin{array}{l}\text { Organisation-related } \\
\text { issues }\end{array}$} & a & $\begin{array}{l}\text { Lacking understanding of learning processes for BIM in maintenance in the early building project stage } \\
\text { Lacking an updated management mode (including people and facilities) for smart BIM-enabled asset management } \\
\text { in the O\&M phase }\end{array}$ \\
\hline & घ & Lacking updated working and services workflows for smart BIM-enabled asset management in the O\&M phase \\
\hline & a & Querying and updating routines are usually manual and time-consuming \\
\hline & घ & BIM and systems are not fully integrated with the asset management workflows \\
\hline \multirow[t]{4}{*}{$\begin{array}{l}\text { Standard-related } \\
\text { issues }\end{array}$} & घ & $\begin{array}{l}\text { Lacking a recognised standard/ specification determining the specific data requirements, BIM implementations, } \\
\text { management processes and strategies in a comprehensive view }\end{array}$ \\
\hline & - & $\begin{array}{l}\text { Standards have often been developed for use within individual life-cycle stages and disciplines, resulting in } \\
\text { discontinuity throughout the asset's whole life }\end{array}$ \\
\hline & a & The developed standards are often generic in nature and fail to address the particular implementation challenges \\
\hline & $\bar{a}$ & $\begin{array}{l}\text { There is little to no alignment between the different standards, resulting in strategic documentation that does not } \\
\text { align to process or technical requirements }\end{array}$ \\
\hline
\end{tabular}


Smart Infrastructure and Construction

Volume 174 Issue 2
Moving from building information

models to digital twins for operation and

maintenance

Lu, Xie, Parlikad, Schooling and Konstantinou

\section{A framework for enhanced DT-enabled asset management in the O\&M phase}

With the basis of comprehensive analysis and limitations, this paper proposes the hierarchical architecture of the DT-enabled asset management framework. In daily O\&M management, compared with BIM, DT is more suitable for complex and comprehensive data management considering the limitations of BIM listed earlier because DTs are built on data and have the capacities of integrating various data resources.

The development of DBB will further accelerate benefits and development of BIM and other digital technologies in the asset management sector based on the momentum created by former efforts. Furthermore, as an authoritative guidance to both researchers and engineers, the report data for public good released by the UK National Infrastructure Commission states that ' $[\mathrm{t}] \mathrm{he}$ UK needs a digital framework for data on infrastructure to harness the benefits from sharing better quality information about its infrastructure; how it is used, maintained and planned' (NIC, 2017: p. 53). Hence, the DT is widely promoted. DT is a digital model that is a dynamic representation of an asset and mimics its real-world behaviours. DT is built on data. However, in research on DTs, a clear-defined and well-organised framework is still needed to supervise their current implementations, identify gaps and provide road maps for future development. Moreover, without such a framework, they are susceptible to omitting some possible improvement and key limitations.

Through a comprehensive literature review, the authors propose a framework for DT-enabled asset management in the O\&M phase. From a practical viewpoint, four aspects of requirements, intelligence, efficiency, integration and interoperability need to be considered for successful implementation of DT-enabled asset management. Intelligence means shifting from traditional manual and labour-intensive asset management to more active and automated approaches (e.g. automatic monitoring process, datadriven approaches and knowledge-led methods). Efficiency means the ability to manage assets in the O\&M phase using effective ways with fewer resources required (e.g. time, cost, FM professionals and computational cost). Integration addresses that all assets (including data, technology and models) can be compatible, integrated and further collaborative. Interoperability describes how DT-enabled asset management can coherently deal with various activities and seamlessly co-operated with other systems/people.

Key layers of achieving 'smart' DT-enabled asset management are summarised and presented in Figure 4.

- Smart asset layer. The term 'smart asset' refers to conducting asset management activities with high performance, such as
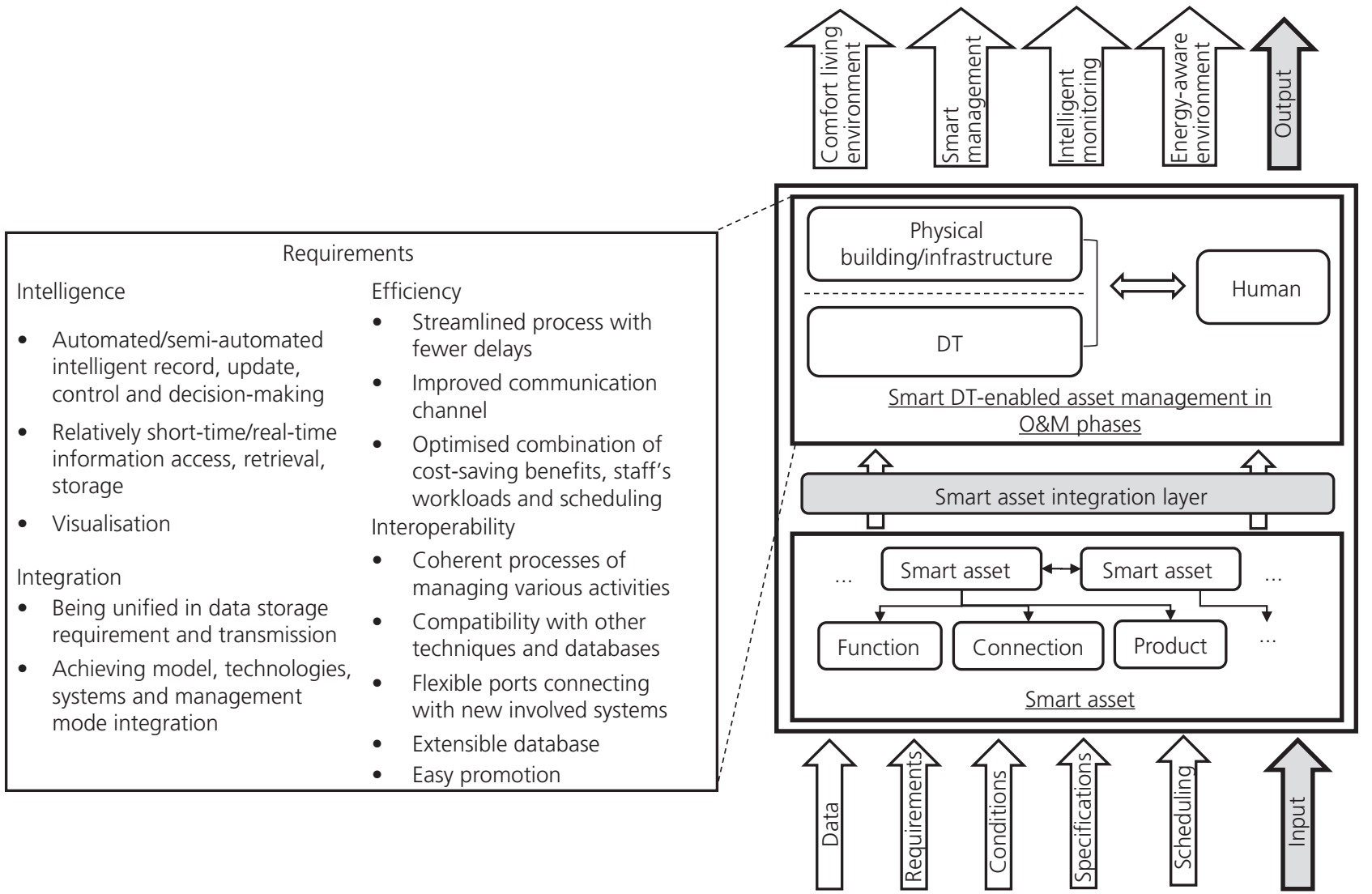

Figure 4. Potential framework of DT-enabled asset management in the O\&M phase 
digital techniques, as-is BIM and information and communication technology, and further has capacities cooperated with other assets. These smart assets will increase productivity in terms of their operational efficiencies in daily services. Due to technological advances (e.g. image-based techniques), contactless data exchange (e.g. radio-frequency identification (RFID)), distributed sensor systems, wireless communication and mobile access (e.g. Wi-Fi environment) are all available in the O\&M phase. Smart assets would be of immense importance for real-time data collection, effective communication and close integration with other assets. Moreover, as-is BIM models will be the central platform linking with different databases and systems in this perspective framework. An as-is BIM is used to describe the up-to-date BIM in the O\&M phase.

- Smart asset integration layer. With the support of smart assets, there is a need to have a layer providing integration and intraoperative services. IoT (including RFID, QR code, sensor systems and network technologies) can support seamless sensing and actuating devices to share information by way of a predefined framework and wireless technologies. Its framework is realised through ubiquitous sensor systems, data analysis, information representation and cloud computing. In the smart asset integration layer, IoT (including RFID, QR code, sensor systems, cloud computing and network technologies) provides open access to various selected subsets of data from their corresponding digital services and supports extensible innovative applications. This layer also can connect assets (including involved people) into interactive and intelligent entirety.

- DT-enabled asset management layer. Successful development of DT-enabled asset management can be achieved from the following four aspects: $(a)$ a clear and well-defined framework for DT-enabled asset management - namely, the perspective framework; $(b)$ an intelligent and seamless plan of integrating all assets during management processes - namely, smart assets and smart asset integration layer; and (c) a practical interoperability method for exchanging and storing information between DT and various FM systems/people namely, the DT and AI-supported decision-making systems. DT will be introduced into this framework. It refers to an integrated multifaceted and multiscale digital replica of physical building/infrastructure, processes and systems. In this framework, the DT integrates IoT, AI, machine learning and existing software analytics with required data to create a dynamic digital platform that updates as-is conditions following the physical building/infrastructure asset. As-is conditions express the current conditions of assets, including work orders, operational information records, FM professional in charge, up-to-date maintenance information and status. Moreover, AI-based intelligent systems would keep learning from experts with rich asset management knowledge for effectively making decisions about daily events and emergency issues. The final aspect is $(d)$ an effective and efficient communication, co-operation and management system for users and FM professionals. For instance, site workers are required to be trained properly to understand the technologies and use the tools developed.

In general, this perspective framework is developed to depict the meaning of DT-enabled asset management. Furthermore, it also provides a consolidated framework for both researchers and practitioners involved in DT or asset management to have a more detailed understanding of how to achieve DT-enabled asset management in the O\&M phase.

\section{Conclusions}

With the extensive attention to implementations of smart asset management in the O\&M phase and the expectations to take all the advantages of BIM and digital techniques in asset management, this paper provides a comprehensive review and analysis, covering both academic publications and industry standards. In order to present the insight into the new field of DTenabled asset management in the O\&M phase, this study gives an overview of academic publications related to BIM-enabled asset management and associated industry standards by summarising various works in different areas and provides possibilities to achieve the goal of transforming to DT-enabled asset management. Detailed limitations and knowledge gaps are discussed, and a perspective framework is also presented. Furthermore, it is also clear that more efforts should be made based on the proposed perspective framework. This effective improvement is an important concern because all assets should be incorporated and integrated seamlessly. Moreover, DT and AI-supported decision-making systems would highly improve the intelligence and integration of the whole system. From the standard aspects, effective and efficient communication, co-operation and management mode would be a close linkage between people and processes.

Future works are, however, needed to do the following: (a) Based on the perspective framework, further the detailed concepts and a case study in real practice of DT-enabled asset management will be developed. (b) DT-enabled asset management at building/ infrastructure will be extended to city-level development; (c) Research should be conducted to investigate the alignment of the proposed framework with the emerging domain of smart cities, specify aligning smart assets with smart cities. (d) The interaction and impact of a smart asset with diverse stakeholders (including customers and the general public) need to be understood better.

\section{Acknowledgements}

The research that contributed to this paper was funded by the Engineering and Physical Sciences Research Council/Innovate UK Centre for Smart Infrastructure and Construction and Centre for Digital Built Britain at the University of Cambridge.

\section{REFERENCES}

Akbarnezhad A, Ong KCG and Chandra LR (2014) Economic and environmental assessment of deconstruction strategies using building information modeling. Automation in Construction 37: 131-144, https://doi.org/10.1016/j.autcon.2013.10.017. 
Smart Infrastructure and Construction

Volume 174 issue 2
Moving from building information

models to digital twins for operation and

maintenance

Lu, Xie, Parlikad, Schooling and Konstantinou
Alvarez-Romero SO (2014) Use of Building Information Modeling Technology in the Integration of the Handover Process and Facilities Management. $\mathrm{PhD}$ thesis, Worcester Polytechnic Institute, Worcester, MA, USA. See https://digitalcommons.wpi.edu/etd-dissertations/380 (accessed 20/08/2019).

Arslan M, Riaz Z and Munawar S (2017) Building Information Modeling (BIM) enabled facilities management using Hadoop architecture. Proceedings of the 2017 Portland International Conference on Management of Engineering and Technology (PICMET), Portland, OR, USA, pp. 1-7.

Aziz ND, Nawawi AH and Ariff NRM (2016) ICT evolution in facilities management (FM): Building Information Modelling (BIM) as the latest technology. Procedia - Social and Behavioral Sciences 234: 363-371.

Becerik-Gerber B, Jazizadeh F, Li N and Calis G (2011) Application areas and data requirements for BIM-enabled facilities management. Journal of Construction Engineering and Management 138(3): 431-442, https://doi.org/10.1061/(ASCE)CO.1943-7862.0000433.

Bentley K and Workman B (2003) Does the Building Industry Really Need to Start Over - a Response from Bentley to Autodesk's BIM/Revit Proposal for the Future. Bentley Systems, Exton, PA, USA.

BSI (2007) BS 1192-2007 +A22016: Collaborative production of architectural, engineering and construction information. Code of practice. BSI, London, UK.

BSI (2013a) PAS 91:2013: Construction prequalification questionnaires. BSI, London, UK

BSI (2013b) PAS 1192-2:2013: Specification for information management for the capital/delivery phase of construction projects using building information modelling. BSI, London, UK.

BSI (2014a) PAS 1192-3:2014: Specification for information management for the operational phase of assets using building information modelling. BSI, London, UK.

BSI (2014b) BS 1192-4:2014: Collaborative production of information. Fulfilling employer's information exchange requirements using COBie. Code of practice. BSI, London, UK.

BSI (2015a) BS 8536-1:2015: Briefing for design and construction. Code of practice for facilities management (buildings infrastructure). BSI, London, UK.

BSI (2015b) PAS 1192-5-2015: Specification for security-minded building information modelling, digital built environments and smart asset management. BSI, London, UK

BSI (2016a) BS 8536-2:2016: Design and construction. Code of practice for asset management (linear and geographical infrastructure). BSI, London, UK.

BSI (2016b) PAS 212:2016: Automatic resource discovery for the Internet of Things. Specification. BSI, London, UK.

Cabinet Office (2013) Government Soft Landings Section 1 Introduction. Cabinet Office, London, UK. See https://www.cdbb.cam. ac.uk/system/files/documents/GovernmentSoftLandingsSection 1 Introduction.pdf (accessed 20/08/2019).

CDBB (Centre for Centre for Digital Built Britain) (2018) The Gemini Principles. See https://www.cdbb.cam.ac.uk/DFTG/GeminiPrinciples (accessed 07/02/2020).

Chen W, Chen K, Cheng JC, Wang Q and Gan VJ (2018) BIM-based framework for automatic scheduling of facility maintenance work orders. Automation in Construction 91: 15-30, https://doi.org/10.1016/ j.autcon.2018.03.007

Chotipanich S (2004) Positioning facility management. Facilities 22(13/14): 364-372, https://doi.org/10.1108/02632770410563086.

Codinhoto R and Kiviniemi A (2014) BIM for FM: a case support for business life cycle. In Product Lifecycle Management for a Global Market (Fukuda S, Bernard A, Gurumoorthy B and Bouras A (eds)). Springer, Berlin, Germany, pp. 63-74.

Dibley M, Li H, Rezgui Y and Miles J (2012) An ontology framework for intelligent sensor-based building monitoring. Automation in Construction 28: 1-14, https://doi.org/10.1016/j.autcon.2012.05.018.
Ding L and Drogemuller R (2009) Towards sustainable facilities management. In Technology, Design and Process Innovation in the Built Environment (Newton P, Hampson K and Drogemuller R (eds)). Spon Press, London, UK, pp. 399-418.

Eastman C, Teicholz P, Sacks R and Liston K (2011) BIM Handbook: a Guide to Building Information Modeling for Owners, Managers, Designers, Engineers and Contractors. Wiley, Hoboken, NJ, USA.

Gray M, Gray J, Teo M, Chi S and Cheung YKF (2013) Building Information Modelling: an international survey. Proceedings of World Building Congress 2013, Brisbane, Australia, pp. 1-14.

Hamledari H, Rezazadeh Azar E and McCabe B (2017) IFC-based development of as-built and as-is BIMs using construction and facility inspection data: site-to-BIM data transfer automation. Journal of Computing in Civil Engineering 32(2): 04017075, https://doi.org/10. 1061/(ASCE)CP.1943-5487.0000727.

Hu ZZ, Tian PL, Li SW and Zhang JP (2018) BIM-based integrated delivery technologies for intelligent MEP management in the operation and maintenance phase. Advances in Engineering Software 115: 1-16, https://doi.org/10.1016/j.advengsoft.2017.08.007.

IAM (Institute of Asset Management) (2014) The Asset Management Landscape. IAM, Bristol, UK. See https://theiam.org/knowledge/ knowledge-base/the-landscape/ (accessed 20/08/2019).

IAM (2015) Asset Management - an Anatomy. IAM, Bristol, UK. See https://theiam.org/knowledge/Knowledge-Base/the-anatomy/ (accessed 20/08/2019).

ISO (International Organization for Standardization) (2007) ISO 120063:2007: Building construction - organization of information about construction works - part 3: Framework for object-oriented information. ISO, Geneva, Switzerland.

ISO (2012) ISO 29481-2:2012: Building information models Information delivery manual - part 2: Interaction framework. ISO, Geneva, Switzerland. See https://www.iso.org/standard/55691.html (accessed 07/02/2022)

ISO (2013) ISO 16739:2013: Industry Foundation Classes (IFC) for data sharing in the construction and facility management industries. ISO, Geneva, Switzerland. See https://www.iso.org/standard/51622.html (accessed 20/08/2019).

ISO (2014a) ISO 55000:2014: Asset management - overview, principles and terminology. ISO, Geneva, Switzerland. See https:/www.iso.org/ standard/55088.html (accessed 20/08/2019).

ISO (2014b) ISO 55001:2014: Asset management - management systems - requirements. ISO, Geneva, Switzerland. See https://www iso.org/standard/55089.html (accessed 20/08/2019).

ISO (2015) ISO 12006-2:2015: Building construction - organization of information about construction works - part 2: framework for classification. ISO, Geneva, Switzerland. See https://www.iso.org/ standard/61753.html (accessed 20/08/2019).

ISO (2016) ISO 29481-1:2016: Building information models information delivery manual - part 1: methodology and format. See https://www.iso.org/standard/60553.html (accessed 20/08/2019).

ISO (2018) ISO 55002:2018: Asset management - management systems guidelines for the application of ISO 55001. ISO, Geneva, Switzerland. See https://www.iso.org/standard/70402.html (accessed 20/08/2019).

Kang TW and Hong CH (2015) A study on software architecture for effective BIM/GIS-based facility management data integration. Automation in Construction 54: 25-38, https://doi.org/10.1016/j. autcon.2015.03.019.

Ko CH, Pan NF and Chiou CC (2013) Web-based radio frequency identification facility management systems. Structure and Infrastructure Engineering 9(5): 465-480, https://doi.org/10.1080/ 15732479.2010 .546804$.

Lee J, Jeong Y, Oh YS et al. (2013) An integrated approach to intelligent urban facilities management for real-time emergency response. Automation in Construction 30: 256-264, https://oi.org/10.1016/j. autcon.2012.11.008. 
Moving from building information

models to digital twins for operation and

maintenance

Lu, Xie, Parlikad, Schooling and Konstantinou
Lin YC and Su YC (2013) Developing mobile-and BIM-based integrated visual facility maintenance management system. Scientific World Journal 2013: 124249, https://doi.org/10.1155/2013/124249.

Lin YC, Su YC and Chen YP (2014) Developing mobile BIM/2D barcodebased automated facility management system. Scientific World Journal 2014: 374735, https://doi.org/10.1155/2014/374735.

Love PE, Matthews J, Lockley S et al. (2015) BIM in facilities management applications: a case study of a large university complex. Built Environment Project and Asset Management 5(3): 261-277, https://doi.org/10.1108/BEPAM-02-2014-0011.

Lu Q, Chen L, Lee S and Zhao X (2018) Activity theory-based analysis of BIM implementation in building O\&M and first response. Automation in Construction 85: 317-332, https://doi.org/10.1016/j.autcon.2017.10. 017.

Matarneh ST, Danso-Amoako M, Al-Bizri S, Gaterell M and Matarneh R (2019) Building information modeling for facilities management: a literature review and future research directions. Journal of Building Engineering 24: 100755, https://doi.org/10.1016/j.jobe.2019. 100755.

Motamedi A, Hammad A and Asen Y (2014) Knowledge-assisted BIMbased visual analytics for failure root cause detection in facilities management. Automation in Construction 43: 73-83, https://doi.org/ 10.1016/j.autcon.2014.03.012.

Motawa I and Almarshad A (2013) A knowledge-based BIM system for building maintenance. Automation in Construction 29: 173-182, https://doi.org/10.1016/j.autcon.2012.09.008.

NIC (National Infrastructure Commission) (2017) Data for the Public Good. NIC, London, UK. See https://www.nic.org.uk/wp-content/ uploads/Data-for-the-Public-Good-NIC-Report.pdf (accessed 20/08/2019).

Parn EA, Edwards DJ and Sing MCP (2017) The building information modelling trajectory in facilities management: a review. Automation in Construction 75: 45-55, https://doi.org/10.1016/j.autcon.2016.12.003.

Parsanezhad P and Dimyadi J (2014) Effective facility management and operations via a BIM-based integrated information system. Proceedings of the 2014 CIB Facilities Management (CFM) Conference, Copenhagen, Denmark.

Peng Y, Lin JR, Zhang JP and Hu ZZ (2017) A hybrid data mining approach on BIM-based building operation and maintenance. Building and Environment 126: 483-495, https://doi.org/10.1016/j.buildenv. 2017.09.030.
Pishdad-Bozorgi P, Gao X, Eastman C and Self AP (2018) Planning and developing facility management-enabled building information model (FM-enabled BIM). Automation in Construction 87: 22-38, https://doi. org/10.1016/j.autcon.2017.12.004.

Sabol L (2008) Challenges in Cost Estimating with Building Information Modeling. Design + Construction Strategies, LLC, Washington, DC, USA.

Sapp D (2015) Whole Building Design Guide. National Institute of Building Sciences, Washington, DC, USA. See http://www.wbdg.org/ om/om.php (accessed 20/08/2019).

Shalabi F and Turkan Y (2016) IFC BIM-based facility management approach to optimize data collection for corrective maintenance. Journal of Performance of Constructed Facilities 31(1): 04016081, https://doi.org/10.1061/(ASCE)CF.1943-5509.0000941.

Shen W, Hao Q and Xue Y (2012) A loosely coupled system integration approach for decision support in facility management and maintenance. Automation in Construction 25: 41-48, https://doi.org/ 10.1016/j.autcon.2012.04.003.

Succar B (2009) Building information modelling framework: a research and delivery foundation for industry stakeholders. Automation in Construction 18(3): 357-375, https://doi.org/10.1016/j.autcon.2008.10. 003.

Suprabhas K and Dib HN (2017) Integration of BIM and utility sensor data for facilities management. In Computing in Civil Engineering 2017: Information Modeling and Data Analytics (Lin KY, El-Gohary N and Tang P (eds)). American Society of Civil Engineers, Reston, VA, USA, pp. 26-33.

Volk R, Stengel J and Schultmann F (2014) Building Information Modeling (BIM) for existing buildings - literature review and future needs. Automation in Construction 38: 109-127, https://doi.org/10. 1016/j.autcon.2013.10.023

Wetzel EM and Thabet WY (2015) The use of a BIM-based framework to support safe facility management processes. Automation in Construction 60: 12-24, https://doi.org/10.1016/j.autcon.2015.09.004

Wilkinson P (2008) SaaS-based BIM. Extranet Evolution, London, UK. See http://extranetevolution.com/2008/04/saas-based-bim/ (accessed 20/08/2019).

Wong JKW, Ge J and He SX (2018) Digitisation in facilities management: a literature review and future research directions. Automation in Construction 92: 312-326, https://doi.org/10.1016/j.autcon.2018.04.006.

\section{How can you contribute?}

To discuss this paper, please email up to 500 words to the editor at journals@ice.org.uk. Your contribution will be forwarded to the author(s) for a reply and, if considered appropriate by the editorial board, it will be published as discussion in a future issue of the journal.

Proceedings journals rely entirely on contributions from the civil engineering profession (and allied disciplines). Information about how to submit your paper online is available at www.icevirtuallibrary.com/page/authors, where you will also find detailed author guidelines. 